Review

\title{
REVIEW OF INFECTION WITH AVIAN PARAMYXOVIRUS SEROTYPE 2 (APMV-2) AND FIRST RESULTS OF BULGARIA
}

\author{
Iv. Zarkov* \\ Department of Microbiology, Infectious and Parasitic Disease, Faculty of Veterinary Medicine, \\ Trakia University, Stara Zagora, Bulgaria
}

\begin{abstract}
The place, antigenic diversity and nomenclature of APMV-2 are successively described. The methods of virus isolation, significance for avian pathology and global distribution of infection through serological, virological surveys and experiments are reviewed. The first investigations with avian blood sera in Bulgaria $(n=253)$ originating from 8 farms from different parts of the country to detect antibodies against APMV-2 are outlined. The data showed spread of infection among hens and chickens with $14.53 \%$ positive samples, and presence of infection in all surveyed farms.
\end{abstract}

Key words: Avian paramyxovirus - 2 (APMV-2), birds, infection, Bulgaria.

\section{INTRODUCTION}

\section{Avian paramyxoviruses from genus} Avulavirus

The Paramyxoviridae family from order Mononegavirales includes important avian representatives. They are classified in subfamily Paramyxovirinae, genus Avulavirus. Avulavirus consists of 9 (nine) serologically distinct paramyxoviruses termed Avian paramyxovirus 19 (APMV 1- 9) (1, 2, 3, 4). A tenth serotype APMV10/penguin/Falkland Islands/324/2007 - is isolated but not definitively classified.

The nomenclature of APMV isolates is similar to that of influenza viruses (5). The name of the strain should contain: 1) the serotype; 2) the species or type of the original host; 3 ) the state or geographical region; 4) strain number (if any); 5) year of isolation. The "Yucaipa" virus refers to APMV-2, as the first isolate was named as APMV$2 /$ chicken/California/Yucaipa/56 and is the prototype of this serological group.

Alexander $(6,7)$ presents one prototype strain of each APMV serotype outlining the most commonly affected hosts as well as other susceptible birds (Table 1).

*Correspondence to: Ivan Zarkov, Department of Microbiology, Infectious and Parasitic Disease, Faculty of Veterinary Medicine, Trakia University, Stara Zagora, Bulgaria,E-mail: ivan_zarkov@abv.bg
The most important avian pathogen is the Newcastle diseases virus (APMV-1). There is no evidence that APMV-2 could infect other species although it is isolated from monkeys (8).

\section{Avian paramyxoviruses serotype 2 (APMV-} 2).

In 1956 Bankowski et al. (9) isolated a paramyxovirus from chickens with respiratory disease affecting the larynx and the trachea. The isolate originated from Yucaipa, California, USA and was named APMV-2/USA(Ca)/Yucaipa/1956. The virus turned out to be serologically distinct from APMV-1 (NDV).

\section{A. Serological investigations in birds}

Serological tests carried out in different domestic and wild bird species have witnessed a wide spread of APMV-2 (10). Antibodies have been established in domestic fowl (chickens, turkeys, ducks, geese, ostriches, peacocks), in cage birds (parrots, pigeons, finches, sparrows) and other decorative and wild avian species (11). APMV-2 is detected in birds in Europe (so far, there are no reports for presence of APMV-2 in birds in Bulgaria), Asia, Africa, North and South America $(12,13)$.

Serological studies of domestic fowl in the USA showed that the virus infected more often turkeys than chickens $(14,15)$. In Spain, $14.7 \%$ of laying hens (341 birds) and 39\% of chickens (123 birds) 
had antibodies against the virus. Antibodies have been reported in $43.7 \%$ of farms with layers and $80 \%$ of chicken farms (1).
Serological tests of blood sera from chickens, ducks, peacocks, ostriches and parrots in China exhibited antibodies in $80 \%$ of parrots, $42-47 \%$ of ostriches, peacocks and chickens, and $25 \%$ of ducks (11).

Table 1. Prototype viruses and APMV hosts

\begin{tabular}{|c|c|c|}
\hline Prototype viruses & Natural hosts & Other hosts \\
\hline APMV-1 = Newcastle disease virus (NDV) & multiple avian hosts & \\
\hline APMV-2/chicken/California/Yukaipa/56 & turkeys, passerine birds & $\begin{array}{l}\text { chickens, psittacine } \\
\text { birds, rails }\end{array}$ \\
\hline APMV-3/turkey/Wisconsin/68* & turkeys & - \\
\hline APMV-3/parakeet/Netherlands/449/75* & $\begin{array}{l}\text { psittacine birds, passerine } \\
\text { birds }\end{array}$ & |- \\
\hline APMV-4/duck/Honk Kong/D3/75 & ducks & geese \\
\hline APMV-5/budgerigar/Japan/Kunitachi/75 & budgerigars & 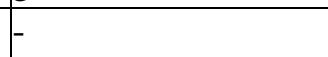 \\
\hline APMV-6/duck/Honk Kong/199/77 & ducks & $\begin{array}{l}\text { geese, turkeys, } \\
\text { rails }\end{array}$ \\
\hline APMV-7/dove/Tennessee/4/75 & pigeons & turkeys, ostriches \\
\hline APMV-8/goose/Delaware/1053/75 & ducks and geese & - \\
\hline APMV-9/duck/New York/22/78 & ducks & - \\
\hline
\end{tabular}

* The types could be distinguished via serological tests with monoclonal antibodies

\section{B. Isolation and identification of APMV-2.}

The sampling methods (cloacal, oropharyngeal, lung homogenates, intestinal homogenates and intestinal content) as well as isolation techniques (8-10-day-old chick embryos) are identical to those for APMV-1 (4).

Madhuri et al., 2010 (16) investigated the mean death times (MDT) of 9-day-old chick embryos and intracerebral pathogenicity index (ICPI) of day-old chicks and reported that MDT was over 168 hours, and ICPI -0 . In another study, Kim et al., 2012 reported MDT values over $144 \mathrm{~h}$ and ICPI -0 .

The haemagglutination activity of all nine APMV serotypes and all 16 avian influenza virus (AIV) subtypes is best shown with chick red blood cells. Serological test (immunodiffusion test, haemagglutination inhibition test) are used for detection of antibodies in blood sera and differentiation of APMV from AIV. Haemagglutination inhibition (HI) is a specific test for distinction of the nine APMVs using typespecific polyclonal sera. Neuraminidase inhibition tests $(17,18,19,20)$, serum neutralization test (20) or agar gel diffusion test $(18,21,22,23) \mathrm{did}$ not result in serotype differentiation.
The HI test results in some cross reactions between serotypes (10), but Lipkind \& Shihmanter, 1986 (24); Lipkind et al., 1986 (25) believe that they are sufficient for distinction. Low-titre cross reactions have been observed among APMV- $1,-3,-4,-7,-8$, and -9 as well as between APMV-2 and -6 .

The isolation of APMV-2 from domestic fowl is less frequent than that of APMV-1 due to lack of purposeful investigations, although the virus has caused problems in chickens and turkeys on a global scale - the USA, Canada, Russia, Japan, Italy, Germany, Israel, India, Saudi Arabia, France, China, Costa Rica, Kenya, Senegal (Alexander, 1980; Alexander, 1985, Guo-zhong Zhang et al, 2006).

The mandatory tests of quarantined imported cage birds often result in APMV-2 isolation, mainly from passerine and psittacine species $(12,26,27)$. Strains have been also isolated from different species parrots, chaffinches, amadinas, finches, Eurasian wrens etc.

The attempts for isolation in freely living birds are also successful, most commonly from passerines and parrots, less frequently from mallards, coots, herons, birds of prey (10). In Senegal parrots for 
export, APMV-2 was isolated from $3.7 \%$ of tested birds (28). In Germany APMV-2 was detected in $31 \%$ of freely living passerine birds (29). For one year in the UK, APMV-2 was isolated from 38 out of $61(62 \%)$ quarantined parrots (30). Over a 8-year period in the USA, APMV-2 was isolated from $46 \%$ of all quarantined birds. In southeastern Asia, $56 \%$ of all cloacal isolates were identified as APMV-2. The infection is the most prevalent between July and September, where young birds are available (31).

\section{Antigenic diversity}

There is little information about the antigenic diversity of most APMV serogroups. The antigenic and structure diversity of APMV-2 is acknowledged $(26,32)$, and it does not reflect on their epidemiological and biological properties. Ozdemir et al., 1990 (33) studies 53 isolates with five types of monoclonal antibodies against haemagglutinin. Isolates were distributed in four groups according to their antigenic relatedness (Table 2). Later, Mahmood et al., 2010 (34) allotted them to 5 groups $(80 \%$ homology) by means of sequence analysis of the $\mathrm{HN}$ gene of 22 isolates, with two subgroups to groups 2 and 4.

Table 2. Groups of APMV-2 isolates after monoclonal antibody test

\begin{tabular}{|l|l|}
\hline Group & Avian isolates \\
\hline First group & $\begin{array}{l}\text { Isolates from parrots, some passerines, } \\
\text { mallards, coots, turkeys }\end{array}$ \\
\hline Second group & Isolates from chickens \\
\hline Third group & Two passerine strains \\
\hline Fourth group & More passerine strains \\
\hline
\end{tabular}

\section{Clinical, virological and serological investigations of APMV-2.}

Health status data in psittacines and passerines with APMV-2 isolates vary within a broad range. Strains have been isolated from asymptomatic birds, birds with milk respiratory signs as well as subjects with severe pneumonia, mucoid tracheitis, diarrhoea, reduced activity and high mortality.

The incubation period in intratracheally infected birds is 4-6 days $(14,15)$.

Chickens and turkeys infected with isolates from cage birds (psittacines and passerines) did not exhibited clinical signs, but immune response (antihaemagglutinins) as well as microscopic changes in the respiratory tract and the pancreas are present (35). Mild respiratory signs were observed in an experiment with 7-day-old chickens and more severe symptoms resulted after co-infection with Mycoplasma or infectious bronchitis virus. APMV-2 is reisolated from the bursa of Fabricius, the trachea, lungs, thymus and more rarely, from the spleen and the kidneys (36). Madhuri et al., 2010 (16) investigated the clinical signs, seroconversion and virus localisation in 4week-old chickens and turkey poults infected with chicken/California/Yukaipa/56 isolate from
Bangkok. The authors did not describe any

clinical signs, but the virus was detected in the respiratory and alimentary tracts with virus shedding. Seroconversion was established on the $6^{\text {th }}$ day post infection.

Chickens infected with APMV-2, 4, 6 from wild birds (35) showed mild respiratory signs and microscopic lesions of trachea, lungs, stomach and pancreas. Antihaemagglutinins were induced only by APMV-2.

The virus is shed from the alimentary and respiratory tracts (37). In natural infections, the virus spread within the flock is slow and not all birds exhibit immune response (38). Spread between closely located flocks is occasionally present (39).

In chickens and turkeys, naturally infected with APMV-2, the virus had caused milk respiratory signs or birds were asymptomatic $(14,40,41)$. More severe symptoms were reported in infected turkeys compared to chickens. Lang et al., 1975 (42) established severe respiratory signs, sinusitis, varying death rates and reduced egg production in APMV-2 infected turkeys. It is demonstrated that observed signs were more severe in cases where 
other viral and/or bacterial agents of disease were also involved. The authors recommended depopulation of poultry flocks infected with the virus as a means of eradication of infection.

It was found out that the APMV-2 was widely prevalent among turkeys in Israel and provoked a respiratory disease at the background of complicated infection (43). In a field experiment, Bankowski et al., 1981 (15) demonstrated that APMV-2 reduced egg production in turkeys without affecting hatchability. There is evidence that APMV-2 could be spread vertically (44).

\section{First reports for avian paramyxovirus-2 (APMV-2) infection in Bulgaria}

Blood sera collected from poultry (136 turkeys; 291 hens and chickens) from 8 farms and 2 private owners from 10 settlements in 4 regions (Razgrad, Burgas, Stara Zagora, Kardzhali) were assayed for detection of post infection antibodies against APMV-2 (an APMV-2 strain from the National Diagnostic and Research Veterinary Medical Institute, Exotic and Emerging Diseases Lab, was used as antigen whose identity was confirmed at Instituto zooprofilattico sperimentale delle venezie - laboratorio virologia - Italia).

The haemagglutination inhibition test was carried out using the method approved by OIE, 2012 (4) with 8 haemagglutination units viral antigen. The results are shown in Table 3.

Table 3. Results from studied avian blood sera screened for antibodies against APMV-2

\begin{tabular}{|l|l|l|l|l|}
\hline $\begin{array}{l}\text { Avian } \\
\text { species }\end{array}$ & $\begin{array}{l}\text { Studied regions/ } \\
\text { positive regions }\end{array}$ & Settlements & $\begin{array}{l}\text { Studied farms/ } \\
\text { positive farms }\end{array}$ & $\begin{array}{l}\text { Studiedsamples/ } \\
\text { positive samples }\end{array}$ \\
\hline Turkeys & $3 / 0$ & 3 & $4 / 0$ & $136 / 0$ \\
\hline $\begin{array}{l}\text { Hens and } \\
\text { chickens }\end{array}$ & $3 / 3$ & 6 & $6 / 6$ & $117 / 17$ \\
\hline
\end{tabular}

The results show that positive results were detected only in hens and chickens $-14.53 \%$ of all studied birds. All farms gave positive results for the infection. The results have shown the presence of APMV-2 infection among poultry in Bulgaria.

\section{CONCLUSIONS}

Results show that in Bulgaria hens and chickens have infection with avian paramyxovirus serotype 2.

\section{REFERENCES}

1. Maldonado, A., Arenas, A., Tarradas, M. C., Luque, I., Astorga, R., Perea, J. A. and Miranda, A. Serological survey for avian paramyxoviruses from wildfowl in aquatic habitats in Andalusia. Journal of Wildlife diseases, 31(1):66-69, 1995.

2. Jørgensen, P. H., Herczeg, J., Lomniczi, B., Manvell, R. J., Holm, E. and Alexander, D.J. Isolation and characterization of avian paramyxovirus type 1 (Newcastle disease) viruses from a flock of ostriches (Struthio camelus) and emus (Dromaius novaehollandiae) in Europe with inconsistent serology. Avian pathology, 27:352-358, 1998.

3. Seal, B. S., King, D. J. and Sellers, H. S. The avian response to Newcastle disease virus. Developmental and Comparative Immunology, 24: 257-268, 2000.
4. OIE. Office International des Epizooties. World Organization for Animals Health. Manual of diagnostic tests and vaccines for terrestrial animals chapter 2.3.14., 2012. http://www.oie.int/international-standardsetting/ terrestrial- manual/ access-online/.

5. WHO. World Health Organization Expert Committee,. A revision of the system of nomenclature for influenza viruses: a WHO memorandum. Bulletin World Health Organisation, 58;585-589, 1980.

6. Alexander, D. J., Newcastle disease -An Avian Paramyxovirus. In: D. J. Alexander, (Ed). Newcastle disease, Development of veterinary virology, Kluwer Academic Publishers, Boston, 11-22, 1988.

7. Alexander, D. J., Newcastle disease, other Avian paramyxoviruses, and Pneumovirus infections. In: Barnes, H. J., Glisson, G. R., Fadly, A. M., McDougald, L. R., Swayne and D. E., Saif, Y. M. (Eds.), Diseases of poultry, $11^{\text {th }}$ ed., Iowa State Press, Blackwell publishing company, 63-92, 2003.

8. Nishikawa, F., Sugiyama, T. and Suzuki, K. A new paramyxovirus isolated from cynomolgus monkeys. Jap. J. Med. Sci . Biol. 30:191-204, 1977.

9. Bankowski, R. A., Corstvet, R. E. and G. T. Clark. Isolation of an unidentified agent from 
the respiratory tract of chickens. Science, 132:292-293, 1960.

10. Alexander, D. J.. The classification, host range and distribution of avian paramyxoviruses. In J. B. McFerran and M. S. McNulty (eds.). Acute Virus Infections of Poultry. Martinus Nijhoff, Dordrecht: The Netherlands, 52-66, 1986.

11.Guo-Zhong Zhang, Zhao, Ji-xun, Ming Wang. Serological survey on prevalence of antibodies to Avian Paramyxovirus serotype 2 in China. Avian Diseases, 51, 1, 137-139, 2007.

12.Alexander, D. J. Avian Paramyxoviruses. Proc $34^{\text {th }}$ West Poult. Dis. Conf., 121-125, 1985.

13. Goodman, B. B. and R. P. Hanson. Isolation of avian paramyxovirus-2 from domestic and wild birds in Costa Rica. Avian Dis, 32:713717, 1988.

14.Bankowski, R. A., Conrad, R. D. and B. Reynolds. Avian influenza and paramyxoviruses complicating respiratory disease diagnosis in poultry. Avian Dis 12:259278, 1968.

15.Bankowski, R. A., Almquist, J. and Dombrucki, J. Effect of paramyxovirus Yucaipa on fertility, hatchability and poult yield of turkeys. Avian Dis. 25:517-520, 1981.

16.Madhuri Subbiah, Sa Xiao, Khattr, S. K., Dias, F. M., Collins, P. L. and Samal, S. K. Pathogenesis of two strains of Avian Paramyxovirus serotype 2 Yucaipa and Bangor in chickens and turkeys. Avian Diseases, 54, 3, 1050-1057, 2010.

17.Kessler, N., Aymard, M. and Calvet, A. Study of a new strain of paramyxoviruses isolated from wild ducks: Antigenic and biological properties. J. Gen. Virol. 43:273-282, 1979.

18.Ishida, M., Nerome, K., Matsumoto, M., Mikami, T. and Oye, A.. Characterization of reference strains of Newcastle disease virus (NDV) and NDV-like isolates by monoclonal antibodies to HN subunits. Arch. Virol. 85:109-121, 1985.

19.Nerome, K., Nakayama, M., Ishida, M., Fukumi, H. and Morita, A. Isolation of a new avian paramyxovirus from a budgerigar. $J$. Gen. Virol. 38:293-301, 1978.

20.Tumova, B., Robinson, J. H. and Easterday, B. C. A hitherto unreported paramyxovirus of turkeys. Res. Vet. Sci. 27:135-140, 1979.

21.Abenes, G. B., Kida, H. and. Yanagawa, R. Avian paramyxoviruses possessing antigenically related $\mathrm{HN}$ but distinct $\mathrm{M}$ proteins. Arch. Virol. 77:71-76, 1983.

22.Alexander, D. J., Hinshaw, V. S.,. Collins, M. S. and Yamane. N. Characterization of viruses which represent further distinct serotypes (PMV-8 and PMV-9) of avian paramyxoviruses. Arch. Virol. 78:29-36, 1983.

23.Kida, H. and Yanagawa, R. Classification of avian paramyxoviruses by immunodiffusion on the basis of the antigenic specificity of their M protein antigens. J. Gen. Virol. 52:103-111, 1981.

24.Lipkind, M., Shihmanter, E., Weisman, Y., Aronovici, A. and Shoham, D. Characterization of Yucaipa-like avian paramyxoviruses isolated in Israel from domesticated and wild birds. Ann. Virol. 133E:157-161, 1982.

25.Lipkind, M. and Shihmanter, E. Antigenic relationships between avian paramyxoviruses. I. Quantitative characteristics based on hemagglutination and neuraminidase inhibition tests. Arch. Virol. 89:89-111, 1986.

26.Alexander, D. J. Avian Paramyxoviruses. Vet. Bull. 50:737-752, 1980.

27.Zhang, Guo-Zhong, Zhao, Ji-xun, Wang, Hong-wei, Yang, Ai-mei, Bu and Chun-ya Ming Wang. Isolation, Identification, and Comparison of Four isolates of Avian Paramyxovirus Serotype 2 in China. Avian Diseases, 50, 3, 386-390, 2006.

28.Fleury, H. and Alexander, D. Isolation of twenty-three Yucaipa-like viruses from 616 wild birds in Senegal, West Africa, Avian Disease, 23, 742-744, 1979.

29.Nymadawa P., Konstantinow-Siebelist, I., Schulze, P. and Starke, G. Isolation of Paramyxoviruses from free-flying birds of the order Passeriformes in German Democratic Republic. Acta Virology, 56, 345-351, 1977.

30.Alexander D. J, Allan, W.H., Parson, G., and Collins M. Identification of paramyxoviruses isolated from birds dying in quarantine in Great Britain. Vet. Rec., 111, 571-574, 1982.

31.Branson W. R. Avian Viruses: function and control, In Linda R. Harrison (Ed), Wingers Publishing, Inc., Post Office Box 6863, Lake Worth, Florida 33466-6863, Chapter 9 Paramyxoviridae, 253 - 283, 1995.

32. Alexander, D. J. and Collins, M. S. The structural polypeptides of avian paramyxoviruses. Arch. Virol. 67:309-323, 1981.

33.Ozdemir, I., Russell, P. H., Collier, J., Alexander, D. J. and Manvell, R. J. Monoclonal antibodies to avian paramyxovirus type 2. Avian Pathol. 19:395- 400, 1990.

34.Mahmood, S, Alexander, D. J., Slomka, M. J., Manvell, R. J., Hanna, A., Fuller, C. M. and 
Brown, I. H. Phylogenetic analysis of the nucleotide sequences for the HN gene of 22 avian paramyxovirus type 2 viruses reveals marked heterogeneity. Avian Pathology, 39(6), 453- 458, 2010.

35.Warke, A, Stallknecht, D. Williams, S. M. Pritchard, N. and Mundt, E. Comparative study on the pathogenicity and immunogenicity of wild bird isolates of avian paramyxovirus 2,4 , and 6 in chickens. Avian Pathology 37(4), 429434, 2008.

36.Wang, Hong-wei, Zhao Ji-xun, Zhao De-ming. Studies on the pathogenecity of Avian Paramyxovirua type 2 (PMV-2). Acta Vet. Zootech. Sin., 33, 169-173, 2002.

37.Alexander D.J., Senne D.A.. Newcastle disease virus and other avian paramyxoviruses. In $\mathrm{A}$ laboratory manual for the isolation, identification, and characterization of avian pathogens, 5th edn, American Association of Avian Pathologists, Athens, Georgia. pp. 135140, 2008.

38.Le Gros F.X. Recent advances in paramyxovirus infection of turkeys in France. In Acute virus infections of poultry: a seminar in the CEC Agricultural Research Programme, Jun.13-14, 1985, Brussels, Belgium, (eds. McFerran JB, McNulty MS), Martinus Nijhoff Publishers, Dordrecht., pp. 96-102, 1986.
39.Alexander D.J. Paramyxovirus infection. In Viral infections of birds (eds. McFerran JB, McNulty MS). Elsevier Science Publishers, Amsterdam, pp. 321-340, 1993.

40.Bradshaw, G. L. and Jensen, M. M. The epidemiology of Yucaipa virus in relationship to the acute respiratory disease syndrome in turkeys. Avian Dis., 23:539-542, 1979.

41.Franciosi, C., D'Aprile, P. N. and Petek, M. Isolamento di un paramixovirus Yucaipa dal tacchino. Boll Ist Sieroter Milan. 60:225-228, 1981.

42.Lang, G., Gagnon, A. and Howell, J. Occurrence of paramyxovirus Yucaipa in Canadian poultry. Can. Vet. J., 16:233-237, 1975.

43.Senne, D. A., Pearson, J. E., Miller, L. D. and Gustafson, G. A. Virus isolations from pet birds submitted for importation into the United States. Avian Dis. 27:731-744, 1983.

44.www.daff.gov.au/.../2336903/APMV-draftpol. Animal Biosecurity, Department of Agriculture, Fisheries and Forestry, Canberra, Australia. Hatching eggs of domestic hens and turkeys - avian paramyxovirus 2 and 3 - draft policy review is available via daff.gov.au., 2013. 